\title{
Notes on the vocalizations of Rufous-naped Wren (Campylorhynchus rufinucha)
}

\section{Peter Boesman}

In the following we briefly analyze and compare voice of the different races of Rufous-naped Wren (Campylorhynchus rufinucha). We also try to quantify the extent of any vocal differences using the criteria proposed by Tobias et al. (2010), as a support for taxonomic review. We have made use of sound recordings available on-line from Xeno Canto (XC).

Voice of the three groups has been studied extensively in Sosa-López et al. (2013), and examination of the available on-line recordings confirms their findings:

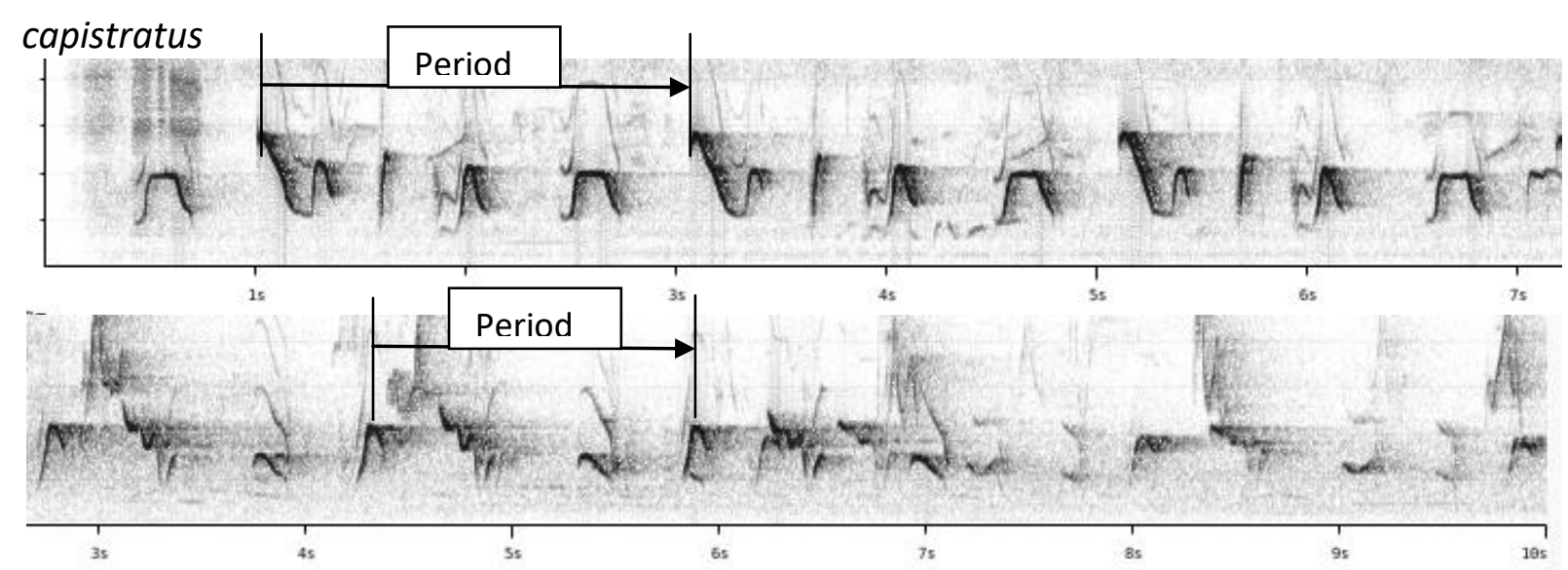

rufinucha
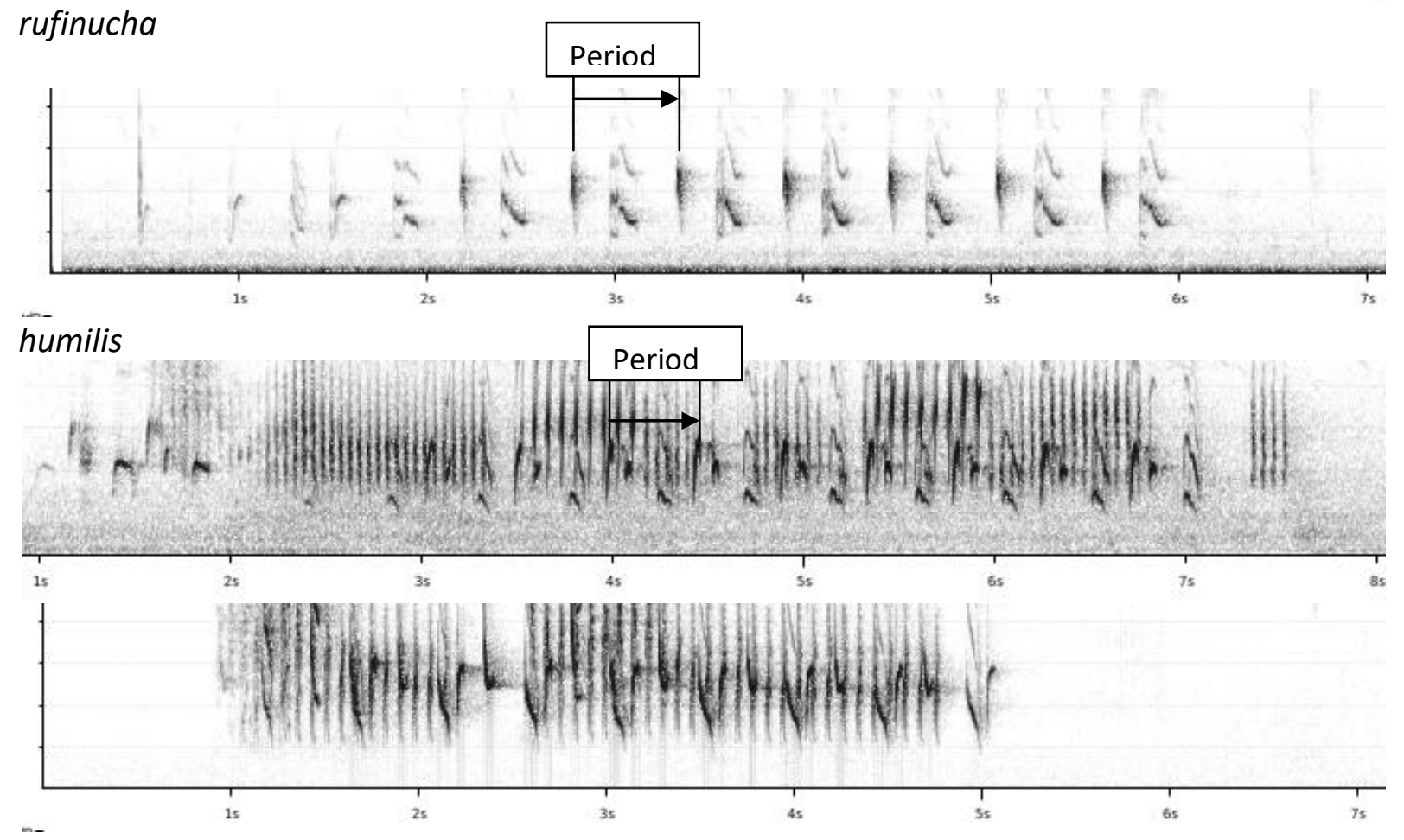

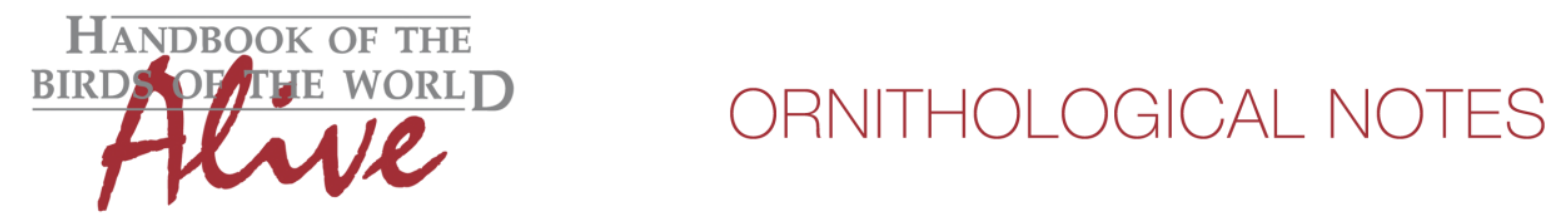

capistratus duets with both birds uttering low-pitched melodious whistles of comparable shape, in perfect synchrony.

rufinucha duets with both birds uttering quite different notes but in perfect synchrony. humilis duets with one bird emiting well-spaced melodious notes and the other bird chattering at a very different pace, asynchronous.

To apply Tobias criteria, we need to identify a number of quantifiable differences:

- the pace (period) with which the same note is repeated is much slower in capistratus (c. $1.5-2 \mathrm{~s}$ interval) vs. less than $1 \mathrm{~s}$ in other 2 groups.

- the total phrase of notes which is repeated consists of 3-4 notes in capistratus, 2 notes in rufinucha and a much higher number in humilis if the chattering of the 2 nd bird is included.

Without digging deeper into the topic, it is clear that the three groups differ vocally in a number of ways.

capistratus differs from rufinucha by duet phrases including more notes (2) which are all of a similar type (while both sexes of rufinucha utter very different notes, score 1-2) and which have a longer period duration (score 2-3).

capistratus differs from humilis by duet phrases including less notes (2) which are all of a similar type (while both sexes of humilis utter very different notes, score 1-2), which are given in synchronous duet (2) and which have a longer period duration (score 2-3).

rufinucha differs from humilis by a synchronous duet (2) with only two notes per period (vs. many more in humilis, score 3 ).

When applying Tobias criteria, this would lead to total vocal score of at least 4 for each pairwise comparison.

This note was finalized on 15th April 2016, using sound recordings available on-line at that moment. We would like to thank in particular the sound recordists who placed their recordings for this species on XC: Nick Athanas, Alfonso Auerbach, Peter Boesman, David Bradley, Robin Carter, Paul Driver, Francisco Dubon, Manuel Grosselet, Jon King, Doug Knapp, Mike Nelson, Andrew Spencer and John van Dort.

\section{References}

Sosa-López, J.R., Mennill, D.J. \& Navarro-Sigüenza, A.G. (2013). Geographic variation and the evolution of song in Mesoamerican rufous-naped wrens Campylorhynchus rufinucha.

J. Avian Biol. 43(1): 1-12.

Tobias, J.A., Seddon, N., Spottiswoode, C.N., Pilgrim, J.D., Fishpool, L.D.C. \& Collar, N.J. (2010). Quantitative criteria for species delimitation. Ibis 152(4): 724-746. 


\section{Recommended citation}

Boesman, P. (2016). Notes on the vocalizations of Rufous-naped Wren (Campylorhynchus rufinucha). HBW Alive Ornithological Note 289. In: Handbook of the Birds of the World Alive. Lynx Edicions, Barcelona. (retrieved from http://www.hbw.com/node/1251731 on 12 October 2016). 